\title{
Influence of Grafting Height and Scion Length on Healing of Graft Union and Growth Characteristics of Citrus reticulata cv. Nagpur Mandarin Grafted on Rough Lemon Rootstocks
}

\author{
Amrita Thokchom ${ }^{*}$, R.K. Dilip Singh ${ }^{2}$, Nesara Begane ${ }^{1}$, \\ Khamrang Mathukmi ${ }^{3}$ and K.S. Sabastian ${ }^{3}$
}
${ }^{1}$ Central Agricultural University, College of Horticulture and Forestry, Pasighat, Arunachal Pradesh, 791102, India
${ }^{2}$ Central Agricultural University, College of Agriculture, Iroisemba, Imphal, Manipur, 795004, India
${ }^{3}$ Department of Horticulture, School of Agricultural Sciences and Rural Development, Medziphema Campus, Nagaland University, Nagaland, 797106, India

*Corresponding author

\begin{tabular}{|c|}
\hline Keywords \\
\hline $\begin{array}{l}\text { Reciprocal } \\
\text { influence, grafting, } \\
\text { Nagpur mandarin }\end{array}$ \\
\hline Article Info \\
\hline $\begin{array}{l}\text { Accepted: } \\
15 \text { February } 2019 \\
\text { Available Online: } \\
10 \text { March } 2019\end{array}$ \\
\hline
\end{tabular}

A B S T R A C T

An experiment was conducted with a view to find out the best grafting height and scion length and the reciprocal influence of the rootstock and scion on grafted citrus cultivar Nagpur mandarin at Horticultural Research Farm, Andro, College of Agriculture, Central Agricultural University, Imphal during 2014 and 2015. The plant material consisted of Nagpur Mandarin as scion and Rough Lemon seedlings as rootstock. The scion with three lengths $(5 \mathrm{~cm}, 10 \mathrm{~cm}$ and $15 \mathrm{~cm})$ were tried at three different heights $(10 \mathrm{~cm}, 15 \mathrm{~cm}$ and 20 $\mathrm{cm})$ from the ground level, comprising 9 treatment combinations (3x3). The two-factor experiment consisting of 9 treatment combinations was laid out in Factorial Randomized Block Design (FRBD) with three replications. Minimum time required for healing of the graft union (24.28) was found non-significant while the growth characteristics such as leaf area, internodal length, root length and diameter, fresh and dry weight of shoots and roots were significantly affected by grafting height and scion length interaction at the end of the observation i.e., 360 days after grafting. The treatment combination $\mathrm{S}_{3} \mathrm{G}_{2}(15 \times 15 \mathrm{~cm})$ was found to produce maximum values while the treatment combination $\mathrm{S}_{1} \mathrm{G}_{1}(5 \times 10 \mathrm{~cm})$ was found to produce minimum values.

\section{Introduction}

Citrus belongs to the sub-family Aurantioideae of the family Rutaceae, is considered to originate from the North East region of India eastward through the Malay
Archipelago, north into China and Japan and south to Australia and also to New Caledonia and New Guinea (Roose et al., 1995). Citrus is valued for the fruit, which is either eaten alone as fresh fruit, processed into juice, pickles or added to dishes and beverages. Citrus is 
known for good sources of bioactive compounds such as citric acid, flavonoids, phenolics, pectins, limonoids, ascorbic acids etc. having properties of antimicrobial, antioxidant, antimutagenic effect, analgesic, anti-inflammatory properties. Bioactive compounds known for treatment of degenerative diseases have wide variation in content among the citrus species (Garg et al., 2001; Dugo and Giacomo, 2002).

Citrus trees are generally propagated both by sexual (seed) as well as asexual (budding, cutting, layering and grafting) means. In India, seed propagation is still practiced in case of acid limes and to produce rootstocks for grafting/budding techniques. Shield or Tbudding is one of the most commonly vegetative propagation techniques. Budding is preformed either in spring or in September. Nevertheless, grafting of citrus is becoming popular with fair amount of success. Grafting is usually done for the production of composite trees from rootstock and scion that possesses specific desirable characters. This technique is also used to change scion cultivars in established orchards, to repair damaged plant parts and serves as a tool in the study of physiological processes and viruses. However, incompatibility of the graft union is one of the greatest obstacles in grafting techniques of fruit plant which is not fully understood. Graft incompatibility results in failure to form a successful graft union, premature death, splitting of the tree at the point of the union, yellowish foliage, early drop and poor growth.

Although, grafting techniques is being utilized by the citrus growers in the North-east region, it requires further investigation for fullest utilization of the technique in terms of grafting height and scion length. With these in view, this research was conducted to find out the best grafting height and scion length for further utilization by citrus growers in NE states for commercial needs.

\section{Materials and Methods}

In this experiment, one year old seedlings of Rough Lemon were used as rootstock and Nagpur mandarin scions for grafting. The grafting operations were carried out simultaneously during the first week of April, 2014. The grafted plants were given uniform cultural treatments and the observations of different parameters were recorded during the years 2014 and 2015.The scion with three lengths $(5 \mathrm{~cm}, 10 \mathrm{~cm}$ and $15 \mathrm{~cm})$ were tried at three different heights $(10 \mathrm{~cm}, 15 \mathrm{~cm}$ and 20 $\mathrm{cm}$ heights from the ground level), comprising 9 treatment combinations $(3 \times 3)$. The twofactor experiment consisting of 9 treatment combinations was laid out in Factorial Randomized Block Design (FRBD) with three replications. For each treatment combination grafting operations were performed on ten rootstocks. Thus, in total grafts $3 \times 3 \times 10 \times 3$ $=270$ were made.

\section{Treatment details}

The experiment consisted of two factors with 9 treatment combinations which were as follows:

\section{FACTOR A: GRAFTING HEIGHT (3) $10 \mathrm{~cm}(\mathrm{G} 1)$ \\ $15 \mathrm{~cm}(\mathrm{G} 2)$ \\ $20 \mathrm{~cm}(\mathrm{G} 3)$}

FACTOR B: SCION LENGTH (3)

$5 \mathrm{~cm}(\mathrm{~S} 1)$

$10 \mathrm{~cm}(\mathrm{~S} 2)$

$15 \mathrm{~cm}(\mathrm{~S} 3)$

\section{Selection of rootstock}

Nearly 11- 12 months old seedling rootstocks of Rough lemon (Citrus jambhiri) raised in the polybags in a nursery of Horticultural Research farm, Andro, College of Agriculture, Central Agricultural University, Imphal were 
used in this experiment. A number of seedlings of healthy, vigorous, straight, strong, pest and disease free having uniform in size and growing in polybags were selected and used.

\section{Selection and collection of scion materials}

Scion is the key factor in successful vegetative propagation by grafting in fruit plant. Quality scion with appropriate growing conditions assures higher percentage of graft success. Therefore, the non-flowering shoots of current season fresh growth having dark green coloured leaves, about $20 \mathrm{~cm}$ long, straight, smooth, healthy, pest and disease free and also of same thickness of rootstock were selected. The scion shoots were of about 3-4 months old containing sufficient reserved food materials. The selected scion shoots were detached from the mother plants with the help of sharp secateurs and were defoliated leaving onefourth of the petiole just after their detachment. The collected scion shoots were then carried in a poly bag to the experimental plots and kept in shady cool place to avoid desiccation.

\section{Grafting operation}

Wedge grafting is one of the simplest and easiest methods and largely used in the propagation of fruit. It is also used in topworking for changing varieties. In this method about 2-3 cm long two smooth slanting cuts were made at the proximal end of the scion on both sides opposite to each other in such a way that the end portion became very thin. It was done with the help of sharp knife. The smooth long slanting cuts at the base of the scion gave an appearance of a sharp chisel. The rootstock was at first beheaded by giving a cut and then a vertical split cut was made by a thin and sharp bladed grafting knife at the centre of the cut surface of the stock having a depth of approximately $2-3 \mathrm{~cm}$. Then, the scion was inserted into the wedge cut of rootstock through slight opening the splits. Thus, both components were brought into close contact particularly cambia in face to face and tied firmly with polythene strip. After wrapping the graft union, the scion along with the union portion was covered with a polythene cap to protect the scion from loss of moisture through transpiration.

The observations were recorded on time taken for healing of the graft union and the growth characteristics such as leaf area, internodal length, root length and diameter, fresh and dry weight of shoots and roots. The collected data on the different parameters of study were statistically analysed to find out the significance of differences between the treatments and treatment combinations. The means of all the treatments were calculated and the analyses of variances (ANOVA) for all the characters were performed by ' $F$ ' variance test. The significance of differences between treatments means were compared by Least Significant Difference (LSD) test (Gomez and Gomez, 1993).

\section{Results and Discussion}

\section{Time taken for healing}

\section{Effect of grafting height}

Different grafting height was found to have no significant influence on time taken for healing of the graft union among the treatments. However, minimum days required for complete healing of the graft union (25.8) was found in graft height $15 \mathrm{~cm}\left(\mathrm{G}_{2}\right)$ followed by $20 \mathrm{~cm}\left(\mathrm{G}_{3}\right)$ (26.43) however, maximum days required was found in graft height $10 \mathrm{~cm}\left(\mathrm{G}_{1}\right)$ (26.59) (Fig. 1 and 2; Table 1).

\section{Effect of scion length}

Different scion length was found to have significant influence on time taken for healing of the graft union. Minimum days required for 
complete healing of the graft union (25.16) was found in scion length $10 \mathrm{~cm}\left(\mathrm{~S}_{2}\right)$ followed by $15 \mathrm{~cm}\left(\mathrm{~S}_{3}\right)$ and maximum days required (27.19) was found in scion length $5 \mathrm{~cm}\left(\mathrm{~S}_{1}\right)$.

\section{Effect of grafting height and scion length interaction}

Grafting height and scion length interaction was found to have non-significant influence on the different treatments on time taken for healing of the graft union. However, minimum days required for complete healing of the graft union (24.28) was observed in treatment combination $\mathrm{S}_{2} \mathrm{G}_{2}(10 \times 15 \mathrm{~cm})$ whereas the maximum days required for complete healing of the graft union (28.61) was recorded in the treatment combination $\mathrm{S}_{1} \mathrm{G}_{1}(5 \times 10 \mathrm{~cm})$.

The minimum time required by the graft combination $\mathrm{S}_{2} \mathrm{G}_{2}(10 \times 15 \mathrm{~cm})$ might have resulted from a closure alignment of cambial layer in stock and scion which is conducive for the rapid formation of the graft union.

\section{Growth characters}

\section{Effect of grafting height}

Parameters such as internode length, number of node, leaf area, root length and diameter, fresh and dry weight of shoots and roots were significantly influence by different grafting heights at the end of the observation. In general, maximum values were observed for almost all these parameters in plants with grafting height $15 \mathrm{~cm}$ than those with 10 and $20 \mathrm{~cm}$ grafting height. However, in case of internode length, grafting height $20 \mathrm{~cm}$ was found to be maximum and $15 \mathrm{~cm}$ to be minimum which is at par with $10 \mathrm{~cm}$ graft height.

Maximum values recorded in $15 \mathrm{~cm}$ grafting height may be due to early sprouting with a consequent higher level of photosynthates and/or dry matter production and as well as greater absorption of nutrient and water from the soil encouraging fast growth. The present finding is in conformity with the earlier work of Singh (2001) who reported that plant growth was significantly affected by grafting height, with grafting at $15 \mathrm{~cm}$ to be the highest in Apple cvs. MM111, M9, M7 and Crab seedling. However, these results are in sharp contrast to the earlier work of Sampaio (1993) who reported that vegetative development of Valencia orange plants were not affected by budding heights of 15,25 and $35 \mathrm{~cm}$ respectively.

\section{Effect of scion length}

The growth characteristics such as internode length, number of node, leaf area, root length and diameter, fresh and dry weight of shoots and roots were also significantly affected by scion length at the end of the observation i.e., 360 days after grafting with scion length 15 $\mathrm{cm}$ recording the maximum values as against the lowest values in $5 \mathrm{~cm}$ graft in almost all the parameters except for length of internode, where maximum value was recorded at $20 \mathrm{~cm}$ and minimum at $10 \mathrm{~cm}$ long scion stick.

The maximum values observed in longer scion in the present findings might be probably due to more food materials reserved that enhanced early bud break and leaf opening, thereby, resulting in maximum growth. Similar results were observed in the earlier work of Majumder et al., (1972) who studied with 5, $7.5,10$ and $12.5 \mathrm{~cm}$ scion length and concluded that the grafts having larger scions made more linear growth of scion shoot in Mango. Sadhu (1992) was also of the view that scions of $15 \mathrm{~cm}$ long in Sapota resulted in taller grafts. In another experiment of Chakrabarty and Sadhu (1984) in Mango, 10 $\mathrm{cm}$ long scions showed better performance than those of 5 and $15 \mathrm{~cm}$ length (Table 2 and $3)$. 
Table.1 Effect of grafting height and scion length on time for healing, internode length and number of nodes

\begin{tabular}{|c|c|c|c|}
\hline Treatment & $\begin{array}{l}\text { TIME TAKEN FOR } \\
\text { HEALING (Days) }\end{array}$ & $\begin{array}{l}\text { INTERNODE } \\
\text { LENGTH }(\mathrm{cm})\end{array}$ & $\begin{array}{l}\text { NUMBER OF } \\
\text { NODES }\end{array}$ \\
\hline \multicolumn{4}{|c|}{ Grafting Height } \\
\hline $\mathbf{G}_{1}$ & 26.59 & 1.69 & 43.88 \\
\hline $\mathbf{G}_{2}$ & 25.8 & 1.61 & 46.17 \\
\hline $\mathbf{G}_{3}$ & 26.43 & 1.76 & 46.09 \\
\hline $\mathrm{SE}(\mathrm{d}) \pm$ & 0.64 & 0.02 & 0.53 \\
\hline $\mathrm{CD}(0.05)$ & NS & 0.04 & 1.12 \\
\hline \multicolumn{4}{|l|}{ Scion Length } \\
\hline $\mathbf{S}_{1}$ & 27.19 & 1.68 & 42.02 \\
\hline $\mathbf{S}_{2}$ & 25.16 & 1.64 & 45.33 \\
\hline $\mathbf{S}_{3}$ & 26.47 & 1.74 & 48.79 \\
\hline $\mathrm{SE}(\mathrm{d}) \pm$ & 0.64 & 0.02 & 0.53 \\
\hline $\mathrm{CD}(0.05)$ & 1.35 & 0.04 & 1.12 \\
\hline \multicolumn{4}{|c|}{$\begin{array}{c}\text { Grafting height and scion length } \\
\text { interaction (SxG) }\end{array}$} \\
\hline $\mathbf{S}_{1} \mathbf{G}_{1}$ & 28.61 & 1.72 & 40.74 \\
\hline $\mathbf{S}_{1} \mathbf{G}_{2}$ & 26.67 & 1.69 & 42.82 \\
\hline $\mathbf{S}_{1} \mathbf{G}_{3}$ & 26.29 & 1.64 & 42.50 \\
\hline $\mathbf{S}_{2} \mathbf{G}_{1}$ & 25.41 & 1.78 & 43.54 \\
\hline $\mathbf{S}_{2} \mathbf{G}_{2}$ & 24.28 & 1.36 & 44.97 \\
\hline $\mathbf{S}_{2} \mathbf{G}_{3}$ & 25.81 & 1.79 & 47.49 \\
\hline $\mathbf{S}_{\mathbf{3}} \mathbf{G}_{\mathbf{1}}$ & 25.76 & 1.59 & 47.37 \\
\hline $\mathbf{S}_{3} \mathbf{G}_{2}$ & 26.44 & 1.77 & 50.73 \\
\hline $\mathbf{S}_{\mathbf{3}} \mathbf{G}_{\mathbf{3}}$ & 27.20 & 1.86 & 48.28 \\
\hline $\mathrm{SE}(\mathrm{d}) \pm$ & 1.10 & 0.04 & 0.92 \\
\hline $\mathrm{CD}(0.05)$ & NS & 0.08 & 1.94 \\
\hline
\end{tabular}

$\mathrm{G}_{1}=10 \mathrm{~cm}, \mathrm{G}_{2}=15 \mathrm{~cm}$ and $\mathrm{G}_{3}=20 \mathrm{~cm} ; \mathrm{S}_{1}=5 \mathrm{~cm}, \mathrm{~S}_{2}=10 \mathrm{~cm}$ and $\mathrm{S}_{3}=15 \mathrm{~cm} ; \mathrm{NS}=$ Non-significant at $5 \%$ level of significance. 
Table.2 Effect of grafting height and scion length on leaf area, root length and root diameter

\begin{tabular}{|c|c|c|c|}
\hline Treatment & $\begin{array}{l}\text { LEAF AREA } \\
\qquad\left(\mathrm{cm}^{2}\right)\end{array}$ & $\begin{array}{c}\text { ROOT LENGTH } \\
(\mathrm{cm})\end{array}$ & $\begin{array}{l}\text { ROOT DIAMETER } \\
(\mathrm{cm})\end{array}$ \\
\hline \multicolumn{4}{|c|}{ Grafting Height } \\
\hline $\mathbf{G}_{1}$ & 54.7 & 47.29 & 14.08 \\
\hline $\mathbf{G}_{2}$ & 63.84 & 58.91 & 16.07 \\
\hline $\mathbf{G}_{3}$ & 59.09 & 50 & 14.48 \\
\hline $\mathrm{SE}(d) \pm$ & 0.79 & 0.64 & 0.28 \\
\hline $\mathrm{CD}(0.05)$ & 1.68 & 1.35 & 0.59 \\
\hline \multicolumn{4}{|l|}{ Scion Length } \\
\hline $\mathbf{S}_{1}$ & 56.88 & 47.76 & 14.42 \\
\hline $\mathbf{S}_{2}$ & 57.35 & 53.03 & 14.56 \\
\hline $\mathbf{S}_{3}$ & 63.40 & 55.41 & 15.65 \\
\hline $\mathrm{SE}(\mathrm{d}) \pm$ & 0.79 & 0.64 & 0.28 \\
\hline $\mathrm{CD}(0.05)$ & 1.68 & 1.35 & 0.59 \\
\hline \multicolumn{4}{|c|}{$\begin{array}{l}\text { Grafting height and scion length } \\
\text { interaction (SxG) }\end{array}$} \\
\hline $\mathbf{S}_{1} \mathbf{G}_{1}$ & 51.70 & 40.77 & 13.93 \\
\hline $\mathbf{S}_{1} \mathbf{G}_{2}$ & 59.50 & 54.13 & 14.98 \\
\hline $\mathbf{S}_{1} \mathbf{G}_{3}$ & 59.43 & 48.37 & 14.34 \\
\hline $\mathbf{S}_{2} \mathbf{G}_{1}$ & 56.87 & 53.63 & 14.21 \\
\hline $\mathbf{S}_{2} \mathbf{G}_{2}$ & 60.82 & 61.23 & 15.09 \\
\hline $\mathbf{S}_{2} \mathbf{G}_{3}$ & 54.37 & 44.10 & 14.39 \\
\hline $\mathbf{S}_{3} \mathbf{G}_{1}$ & 55.53 & 47.47 & 14.09 \\
\hline $\mathbf{S}_{3} \mathbf{G}_{2}$ & 71.20 & 61.37 & 18.14 \\
\hline $\mathbf{S}_{\mathbf{3}} \mathbf{G}_{\mathbf{3}}$ & 63.47 & 57.53 & 14.71 \\
\hline $\mathrm{SE}(d) \pm$ & 1.24 & 1.10 & 0.48 \\
\hline $\mathrm{CD}(0.05)$ & 2.63 & 2.33 & 1.02 \\
\hline
\end{tabular}

$\mathrm{G}_{1}=10 \mathrm{~cm}, \mathrm{G}_{2}=15 \mathrm{~cm}$ and $\mathrm{G}_{3}=20 \mathrm{~cm} ; \mathrm{S}_{1}=5 \mathrm{~cm}, \mathrm{~S}_{2}=10 \mathrm{~cm}$ and $\mathrm{S}_{3}=15 \mathrm{~cm} ; \mathrm{NS}=$ Non-significant at $5 \%$ level of significance 
Table.3 effect of grafting height and scion length on fresh weight and dry weight of shoot and root

\begin{tabular}{|c|c|c|c|c|}
\hline Treatment & $\begin{array}{l}\text { FRESH WEIGHT OF } \\
\text { SHOOT }(\mathrm{g})\end{array}$ & $\begin{array}{l}\text { DRY WEIGHT OF } \\
\text { SHOOT }(\mathrm{g})\end{array}$ & $\begin{array}{c}\text { FRESH WEIGHT OF } \\
\text { ROOT (g) }\end{array}$ & $\begin{array}{l}\text { DRY WEIGHT OF } \\
\text { ROOT (g) }\end{array}$ \\
\hline \multicolumn{5}{|c|}{ Grafting Height } \\
\hline $\mathbf{G}_{1}$ & 18.19 & 7.93 & 7.94 & 4.11 \\
\hline $\mathbf{G}_{2}$ & 30.42 & 13.99 & 13.77 & 6.57 \\
\hline $\mathbf{G}_{3}$ & 22.14 & 10.13 & 10.20 & 4.68 \\
\hline $\mathrm{SE}(d) \pm$ & 0.30 & 0.17 & 0.11 & 0.08 \\
\hline $\mathrm{CD}(0.05)$ & 0.64 & 0.35 & 0.24 & 0.17 \\
\hline \multicolumn{5}{|l|}{ Scion Length } \\
\hline $\mathbf{S}_{1}$ & 20.90 & 9.70 & 9.45 & 4.68 \\
\hline $\mathbf{S}_{\mathbf{2}}$ & 23.83 & 10.74 & 10.60 & 5.25 \\
\hline $\mathbf{S}_{\mathbf{3}}$ & 26.03 & 11.62 & 11.87 & 5.42 \\
\hline $\mathrm{SE}(\mathrm{d}) \pm$ & 0.30 & 0.17 & 0.11 & 0.08 \\
\hline $\mathrm{CD}(0.05)$ & 0.64 & 0.35 & 0.24 & 0.17 \\
\hline \multicolumn{5}{|c|}{$\begin{array}{l}\text { Grafting height and scion length } \\
\text { interaction (SxG) }\end{array}$} \\
\hline $\mathbf{S}_{1} \mathbf{G}_{1}$ & 15.16 & 6.76 & 6.96 & 3.59 \\
\hline $\mathbf{S}_{1} \mathbf{G}_{2}$ & 30.86 & 14.47 & 13.70 & 6.42 \\
\hline $\mathbf{S}_{1} \mathbf{G}_{3}$ & 16.69 & 7.88 & 7.68 & 4.04 \\
\hline $\mathbf{S}_{2} \mathbf{G}_{1}$ & 23.47 & 9.96 & 8.24 & 4.51 \\
\hline $\mathbf{S}_{2} \mathbf{G}_{2}$ & 26.87 & 12.11 & 12.99 & 6.39 \\
\hline $\mathbf{S}_{2} \mathbf{G}_{3}$ & 21.16 & 10.14 & 10.55 & 4.86 \\
\hline $\mathbf{S}_{\mathbf{3}} \mathbf{G}_{\mathbf{1}}$ & 15.96 & 7.09 & 8.63 & 4.22 \\
\hline $\mathbf{S}_{3} \mathbf{G}_{2}$ & 33.54 & 15.41 & 14.63 & 6.90 \\
\hline $\mathbf{S}_{\mathbf{3}} \mathbf{G}_{\mathbf{3}}$ & 28.59 & 12.37 & 12.36 & 5.15 \\
\hline $\mathrm{SE}(\mathrm{d}) \pm$ & 0.52 & 0.29 & 0.20 & 0.14 \\
\hline $\mathrm{CD}(0.05)$ & 1.11 & 0.61 & 0.42 & 0.30 \\
\hline
\end{tabular}

$\mathrm{G}_{1}=10 \mathrm{~cm}, \mathrm{G}_{2}=15 \mathrm{~cm}$ and $\mathrm{G}_{3}=20 \mathrm{~cm} ; \mathrm{S}_{1}=5 \mathrm{~cm}, \mathrm{~S}_{2}=10 \mathrm{~cm}$ and $\mathrm{S}_{3}=15 \mathrm{~cm} ; \mathrm{NS}=$ Non-significant at $5 \%$ level of significance 
Fig.1\&2 Healed plant \& A successful graft union

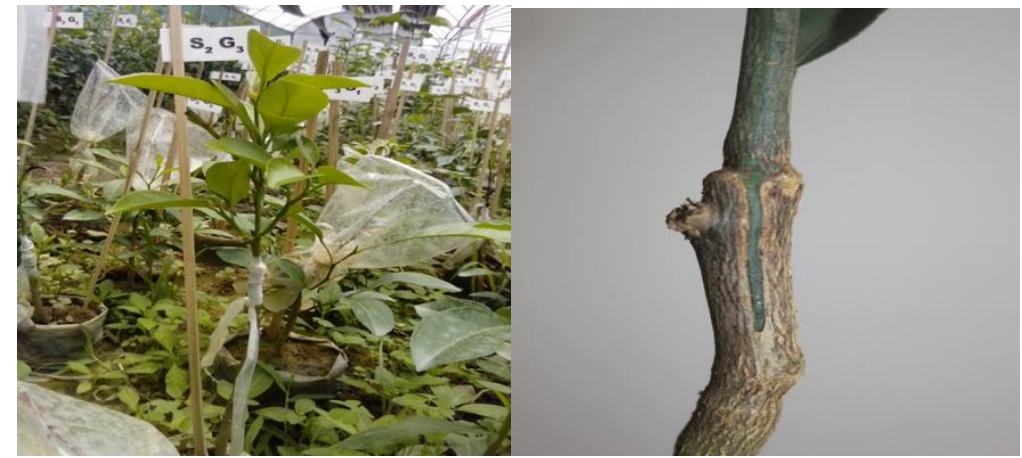

However, Kanwar and Bawja (1974) reported that there was no appreciable effect of length of scions on the linear growth of successful grafts.

\section{Effect of Grafting Height and Scion Length Interaction}

Internode length, number of node, leaf area, root length and diameter, fresh and dry weight of shoots and roots were also significantly affected by grafting height and scion length at the end of the observation i.e., 360 days after grafting. The treatment combination $\mathrm{S}_{3} \mathrm{G}_{2}(15$ $\mathrm{x} 15 \mathrm{~cm}$ ) was found to produce maximum values and treatment combination $\mathrm{S}_{1} \mathrm{G}_{1}(5 \mathrm{x}$ $10 \mathrm{~cm}$ ) was found to produce minimum values.

The highest value observed in the treatment combination $S_{3} G_{2}(15 \times 15)$ may be ascribed to its ability to build up more of the photosynthates and its subsequent partitioning thereby resulting into development of greater framework such as height, leaf area, number of nodes, diameter of the stem and total root volume etc.

\section{References}

Chakkrabaty, U. and Sadhu, M.K. (1984). Effect of age and length of rootstock and scion on the success of epicotyl grafting in mango. Indian J. Agric. Sci.,
54(12): 1066-1072.

Dugo, G. and Giacomo, A. (2002).Citrus: the genus citrus. Taylor and Francis, New York.

Garg, A., Garg, S., Zaneveld, L.J.D. and Singla, A.K. (2001). Chemistry and Pharmacology of the citrus bioflavonoid hespridin. Phytother. Res., 15: 655-669.

Gomez, K.A. and Gomez, A.A. (1993). Statistical Procedure for Agricultural Research. (2nd ed.). John Willey and Sons, New York. pp. 28-192.

Kanwar, J.S. and Bawja, M.S. (1974). Propagation of mango by side grafting. Indian J. Agric. Sci., 44(5): 270-272.

Majumder, P.K., Mukherjee, S.K. and Rathore, D.S. (1972). Further researches on propagation techniques in Mango. Acta Hort., 24: 72-73.

Roose, M.L., Soost, R.K. and Cameroon, J.W. (1995). Citrus. In: Smartt, J. and Simmonds, N.W. (ed) Evolution of crop plants, 2nd edn. Longman, UK. pp. $443-$ 448.

Sadhu, M.K. (1992). Standardization of grafting techniques in Sapota (Actraszapota L.). ActaHortic., 321: 610-615.

Sampaio, V.R. (1993). Effects of Poncirus trifoliate interstocks and budding height of Valencia Orange on Rangpur Lime rootstock. Sci. Agric., doi: 10. 1590/s0103-90161993000300007.

Singh, R.K. (2001). Studies on rootstock, 
scion and interstock growth interactions in Apple. PhD. Thesis submitted to College of Hortic., Dr.Yashwant Singh
Parmar University of Horticulture and Forestry, Nauni, Solan, India.

\section{How to cite this article:}

Amrita Thokchom, R.K. Dilip Singh, Nesara Begane, Khamrang Mathukmi and Sabastian, K.S. 2019. Influence of Grafting Height and Scion Length on Healing of Graft Union and Growth Characteristics of Citrus reticulata cv. Nagpur Mandarin Grafted on Rough Lemon Rootstocks. Int.J.Curr.Microbiol.App.Sci. 8(03): 2066-2074.

doi: https://doi.org/10.20546/ijcmas.2019.803.246 